\title{
Persepsi Pemahaman Pengusaha dalam Penyusunan Laporan Keuangan Berdasarkan SAK EMKM pada UMKM Kabupaten Jepara
}

\author{
Yanto $^{1}$ \\ ${ }^{1}$ Universitas Islam Nahdlatul Ulama, Tahunan RT 01 RW 01, Jepara, 59427, Indonesia
}

ISSN-P: 2338-6010

ISSN-E: 2721-3692

\begin{abstract}
The problem in developing Micro, Small and Medium Enterprises (MSMEs) is the lack of understanding of MSMEs in preparing financial reports based on SAK EMKM. The research aims to analyze information and socialization, education, length of business, and size of business to influence the understanding of MSMEs in preparing financial reports based on SAK EMKM. The research was conducted on 66 furniture MSME entrepreneurs in Jepara District. The research was conducted by distributing questionnaires and analyzed using multiple regression analysis and hypothesis testing $t$. The results showed that information and socialization had a significant positive effect on the preparation of financial statements based on SAK EMKM; education has a significant positive effect on the preparation of financial statements based on SAK EMKM; length of business has a significant positive effect on the preparation of financial statements based on SAK EMKM, and business size has a significant positive effect on the preparation of financial statements based on SAK EMKM.
\end{abstract}

Keywords: Information; Duration; Financial Statements; Education; and Size.

\section{ABSTRAK}

Permasalahan dalam mengembangkan Usaha Mikro Kecil Menengah (UMKM) adalah kurangnya kemampuan pemahaman UMKM dalam penyusunan laporan keuangan berdasarkan SAK EMKM. Penelitian bertujuan menganalisis Informasi dan Sosialisasi, pendidikan, lama usaha dan ukuran usaha mempengaruhi pemahaman UMKM dalam penyusunan laporan keuangan berdasarkan SAK EMKM. Penelitian dilakukan pada 66 Pengusaha UMKM furniture meubel di Kecamatan Jepara. Data penelitian dikumpulkan dengan cara menyebarkan kuesioner kepada para pengusaha dan dianalisis menggunakan analisis regresi berganda dan pengujian hipotesis $t$. Hasil penelitian diketahui informasi dan sosialisasi berpengaruh positif signifkan terhadap penyusnan laporan keuangan berdasarkan SAK EMKM; pendidikan berpengaruh positif signifkan terhadap penyusnan laporan keuangan berdasarkan SAK EMKM; lama usaha berpengaruh positif signifkan terhadap penyusnan laporan keuangan berdasarkan SAK EMKM, dan ukuran usaha berpengaruh positif signifkan terhadap penyusnan laporan keuangan berdasarkan SAK EMKM. . Kata Kunci: Informasi; Lama; Laporan Keuangan; Pendidikan; dan Ukuran.

\section{PENDAHULUAN}

Usaha Mikro, Kecil dan Menengah (UMKM) merupakan kegiatan ekonomi rakyat yang berdiri sendiri dan berskala kecil serta dikelola oleh kelompok masyarakat menengah atau keluarga. UMKM sendiri sangat mempengaruhi perekonomian nasional, karena dapat menyerap jumlah pengangguran di Indonesia yang sangat tinggi dan memberikan kontribusi tinggi terhadap produk Domestik Bruto. Kementerian Keuangan (Kemenkau) mencatat UMKM memiliki kontribusi sebesar 60,3\% dari total produk domestik bruto (PDB) Indonesia. Selain itu, UMKM menyerap 97\% dari total tenaga kerja dan 99\% dari total lapangan kerja. Pada 2018, UMKM tercatat sebanyak 64,2 juta unit (https:// databoks.katadata.co.id/2020).

Indonesia sudah menghadapi Asean Economic Community (AEC), dimana persaingan pasar akan semakin tinggi bagi pelaku UMKM. Jika UMKM tidak melakukan inovasi dan pengembangan usahanya, maka bisa jadi banyak pelaku UMKM yang tidak bisa melanjutkan usahanya. Salah satu upaya untuk menjaga kontinyuitas usaha adalah dengan melakukan penyusunan laporan keuangan. Dengan laporan keuangan, pengusaha akan mengetahui dengan pasti kondisi UMKM-nya. Untuk penyusunan laporan keuangan pada UMKM sejak 1 Januari 2018 sudah mengacu dengan Standar Akuntansi Keuangan Entitas Mikro Kecil dan Menengah (SAK EMKM). Alasan dibuatnya SAK EMKM ini adalah dikarenakan banyak pelaku usaha EMKM atau UMKM yang belum mengetahui cara membuat Laporan Keuangan secara lengkap, mendetail dan komprehensif. Sedangkan Laporan Keuangan merupakan instrumen yang penting 
bagi kegiatan bisnis dalam melaporkan segala transaksi dari seluruh aktivitas bisnis UMKM.

Laporan keuangan adalah laporan yang menggambarkan dampak keuangan dan transaksi dan peristiwa lain yang diklasifikasikan dalam berapa kelompok besar menurut karakteristik ekonominya (IAI, 2002 : par 47). Laporan keuangan berfungsi sebagai salah satu sumber informasi untuk megambil suatu kebijakan-kebijakan dalam hal persaingan. Laporan Keuangan menurut SAK EMKM dibuat berdasarkan asumsi dasar akrual dan kelangsungan usaha seperti entitas bisnis umumnya. Syarat penyajian Laporan Keuangan UMKM harus bersifat relevan, lengkap, bisa dipahami, dan komparatif. Sesuai dengan peraturan SAK EMKM, minimal UMKM harus membuat tiga jenis laporan keuangan berikut ini: 1) Laporan Posisi Keuangan; 2) Laporan Laba Rugi; dan 3) Catatan Atas Laporan Keuangan (CALK).

Banyak faktor yang mepengaruhi pelaku usaha EMKM atau UMKM yang belum mengetahui cara membuat Laporan Keuangan. Dari beberapa hasil penelitian ditunjukkan faktor-faktor yang mempengaruhi penyusunan laporan keuangan menurut Tuti dan Dwijayanti (2016) antara lain: pemberian informasi dan sosialisasi, latar belakang pendidikan, jenjang pendidikan, lama usaha ukuran usaha. Menurut Wicaksono (2016) yang mempengaruhi penyusunan laporan keuangan yaitu jenjang pendidikan, ukuran usaha, lama usaha, keikutsertaan dalam pelatihan. Dan menurut Maharani (2016) yang mempengaruhi penyusunan laporan keuangan yaitu pemberian informasi dan sosialisasi, latar belakang pendidikan, jenjang pendidikan pemilik, lama usaha, ukuran usaha. Dalam penelitian ini faktor-faktor yang mempengaruhi penyusunan pembuatan laporan keuangan ditentukan yaitu informasi dan sosalisasi, latar belakang pendidikan, lama usaha, dan ukuran usaha. Penelitian ini dilakukan untuk memenuhi saran dari Wicaksono (2016) untuk menambah varaibel penelitian, sehingga penelitian ini mengambil variabel informasi dan sosalisasi, hal ini didasarkan karena terdapat hasil penelitian terdahulu yang tidak konsisten. Ditunjukkan hasil penelitian Maharani (2016) informasi dan sosialisasi berbengaruh positif signifikan terhadap pemahaman UMKM dalam menyusun laporan keuangan berdasarkan SAK ETAP, sedangkan penelitian Tuti dan Dwijayanti (2016) didapat informasi dan sosialisasi berpengaruh negatif terhadap pemahaman UMKM pada laporan keuangan berdasarkan SAK ETAP.

Informasi dan sosialisasi adalah transfer atau penyampaian sebuah informasi pengetahuan kepada orang lain dengan tujuan orang tersebut mengetahui atau informasinya akan bertambah (Soekanto, 2009). Jadi apabila seseorang memperoleh informasi dan sosialisasi tentang informasi akuntansi akan menjadikan orang tersebut memilki pengetahuan yang lebih banyak lagi sehingga akan mebuat mereka lebih paham lagi dalam menyusun laporan keuangan. Latar belakang pendidikan merupakan pendidikan yang ditempuh seseorang pemilik UMKM (Rudianto dan Siregar, 2011). Seseorang dengan latar belakang pendidikan ekonomi/akuntansi cenderung lebih mudah memahami pembuatan laporan keuangan berdasarkan SAK EMKM dibandingkan seseorang yang bukan berlatar belakang pendidkan ekonomi/akuntansi karena belum memiliki pondasi ilmu yang kuat dalam bidang akuntansi, sehingga akan kesulitan dalam penyusunan laporan keuangan. Jadi latar belakang pendidikan dapat mempengaruhi seseorang dalam memahami pembuatan laporan keuangan berdasarkan SAK EMKM.

Lama usaha ditunjukan berdasarkan umur perusahaan berdasarkan tahun sejak pendirian peruahaan sampai dengan penelitian ini dilakukan (Rudiantoro, 2012). Purnamasari (2009) yang menyatakan bahwa seiring dengan lamanya sebuah usaha berdiri, maka pengalaman yang dimiliki oleh usaha tersebut akan semakin bertambah. Jadi semakin lama berdirinya sebuah usaha maka akan memiliki pengalaman yang lebih banyak lagi terutama dalam hal pembuatan laporan keuangan, sehingga akan mendorong pengusaha usaha untuk melakukan penyusunan laporan keuangan berdasarkan SAK EMKM. Ukuran usaha adalah ukuran besar kecilnya sebuah usaha menurut Rudiantoro dan Siregar (2011) yang menyatakan semakin meningkat pertumbuhan sebuah UMKM maka kebutuhan akan adanya laporan keuangan yang sesuai standar akuntansi akan semakin tinggi. Oleh karena itu, semakin besarnya ukuran sebuah usaha maka semakin banyak pula pengalaman dalam membuat laporan keuangan berdasarakan SAK EMKM.

\section{Landasan Teori \\ Informasi Dan Sosialisasi}

Informasi menurut Jogiyanto (2010) ialah hasil dari pengolahan data dalam bentuk yang lebih bermanfaat dan lebih berarti bagi penerimanya yang menggambarkan suatu kejadian (event) yang nyata (fact) yang berguna untuk pengambilan keputusan di dalam perusahaan. Menurut Kadir (dalam Alva, 2010) informasi sebagai data yang diolah sehingga menghasilkan peningkatan pengetahuan seseorang yang menggunakan data tersebut. Kalau informasi dikaitkan dengan akuntansi, Baridwan (2000) 
Jurnal Akuntansi \& Perpajakan

Vol. 7 (1) 2021: 17-30

mengemukakan bahwa informasi akuntansi merupakan bagian yang sangat penting dari keseluruhan informasi yang dibutuhkan oleh para manajemen. Informasi akuntansi terutama berhubungan dengan data keuangan dari suatu perusahaan. Agar data keuangan tersebut dapat dimanfaatkan dengan baik oleh manajemen atau pihak luar perusahaan yang memerlukannya, maka informasi tersebut harus disajikan dalam bentuk laporan salah satunya yaitu laporan keuangan. Dapat disimpulkan bahwa informasi akuntansi merupakan suatu alat yang digunakan untuk mengambil sebuah keputusan, terutama untuk pelaku bisnis UMKM. Informasi akuntansi sendiri diharapkan bisa digunakan sebagai sistem informasi yang dapat mengukur dan mengkomunikasikan informasi keuangan tentang kegiatan ekonominya. Informasi yang sudah dihasilkan dari sebuah laporan keuangan tersebut berguna dalam rangka menyusun berbagai proyeksi, misal kebutuhan uang kas.

Sosialisasi adalah proses yang membantu individu-individu belajar dan menyesuaikan dirinya, bagaimana cara hidup, dan berpikir kelompoknya agar ia dapat berperan dan berfungsi dengan kelompoknya. Menurut Soekanto (2009) sosialisasi adalah proses mengkomunikasikan kebudayaan kepada warga masyarakat yang baru. Jadi dapat disimpulkan bahwa sosialisasi merupakan bentuk keseluruhan kebiasaan yang dimiliki manusia dibidang tertentu dan sebagianya harus dipelajari oleh setiap anggota baru msyarakat melaui proses yang dinamakan sosialisasi.

\section{Latar Belakang Pendidikan}

Latar belakang pendidikan merupakan usaha sadar dan terencana untuk mewujudkan suasana belajar dalam proses pembelajaran agar peserta didik semakin aktif dalam mengembangkan potensi dirinya untuk memiliki kekuatan spiritual keagamaan, pengendalian diri, kepribadian, ahlak mulia, kecerdasan serta sebuah ketrampilan yang dibutuhkan dirinya maupun masyarakat. Latar belakang pendidikan adalah latar belakang pendidikan formal atau non formal, sarjana seterusnya dan jurusan apa yang diambil ketika menempuh pendidikan tesebut. Pendidikan nasional berfungsi mengembangkan kemampuan dan membentuk watak serta peradaban bangsa yang bermartabat dalam rangka mencerdaskan kehidupan bangsanya, bertujuan untuk mengembangkan potensi peserta didik agar menjadi manusia yang beriman dan bertaqwa kepada Tuhan Yang Maha Esa, berakhlak mulia, sehat, berilmu, cakap, kreatif, mandiri, dan menjadi warga Negara yang demokratis serta bertanggung jawab (Depdiknas, 2003).

\section{Lama Usaha}

Lama usaha ditunjukan berdasarkan umur perusahaan berdasarkan tahun sejak pendirian peruahaan sampai dengan penelitian ini dilakukan (Rudiantoro, 2012). Dengan asumsi bahwa semakin lama usaha tersebut berjalan, maka akan mengakibatkan adanya perkembangan usaha yang signifikan kearah yang positif atau negatif. Perkembangan dari tersebut tergantung dari iklim perdagangan dan persaingan yang terjadi di dunia maupun di pangsa pasarnya juga. Biasanya usaha yang lebih lama berdiri cenderung lebih berkembang karena sudah memiliki banyak pengalaman dalam menjalankan usahanya tersebut. Dan juga usaha yang memiliki umur usaha yang bisa dibilang mapan lebih bisa bersaing dengan usaha atau pelaku UMKM lainnya.

\section{Ukuran Usaha}

Pengertian ukuran usaha menurut Sujiono dan Sujiono (2010) menggambarkan besar kecilnya sebuah perusahaan yang ditunjukan oleh total seluruh aktiva, jumlah penjualan, rata rata total penjualan dan ratarata total aktiva. Jadi ukuran perusahaan merupakan ukuran atau besarnya asset yang dimiliki oleh perusahaan. Ukuran usaha merupakan skala yang menunjukan besar kecilnya sebuah perusahaan, dilihat dari jumlah kariawan, volume penjualan dan nilai aset yang dimiliki (Longenecker, 2001 dalam Tuti dan Dwijayanti, 2016). Jadi bisa dikatakan jumlah pendapatan atau penjualan yang dihasilkan oleh sebuah perusahaan dapat menunjukkan perputaran asset atau modal yang dimiliki perusahaannya semakin besar pula kompleksitas perusahaan dalam menggunakan informasi akuntansi. Jumlah karyawan dapat menunjukkan berapa kapasitas perusahaan dalam mengoperasionalkan usahanya, semakin besar jumlah karyawan semakin besar pula tingkat kompleksitas perusahaan, sehingga informasi akuntansi sangat dibutuhkan. 


\section{Laporan Keuangan Berdasarkan SAK EMKM Usaha}

Usaha Mikro Kecil Menengah adalah sebuah entitas yang berskala kecil dan dikelola oleh Masyarakat menengah atau bisnis yang dijalankan oleh keluarga sendiri. Usaha yang bukan anak perusahaan atau sebuah cabang perusahaan, Berdasarkan UU Nomor 20 Tahun 2008 tentang UMKM (Usaha Mikro Kecil Menengah) adalah usaha produktif milik orang perorangan atau badan usaha perorangan yang memenuhi kriteria Usaha Mikro sebagaimana diatur dalam Undang-Undang. Kriteria Usaha Mikro yaitu: 1) Memiliki kekayaan bersih paling banyak Rp. 50.000.000,00 tidak termasuk tanah dan bangunan tempat usaha; 2) Memiliki hasil penjualan tahunan paling banyak Rp. 300.000.000,00. Kriteria Usaha Kecil yaitu: 1) Memiliki kekayaan bersih lebih dari Rp. 50.000.000,00 sampai dengan Rp. 500.000.000,00 tidak termasuk tanah dan bangunan tempat usaha; 2) atau memiliki hasil penjualan tahunan lebih dari Rp. 300.000.000,00 sampai dengan Rp. 2.500.000.000,00. Kriteria Usaha Menengah yaitu: 1) Kekayaan bersih lebih dari Rp. 500.000.000,00 sampai dengan Rp. 10.000.000.000,00 tidak termasuk tanah dan bangunan tempat usaha; 2) Mempunyai hasil penjualan tahunan lebih dari Rp2.500.000.000,00 sampai dengan Rp. 50.000.000.000,00.

Laporan keuangan menurut PSAK No.1 (2015) adalah penyajian terstruktur dari posisi keuangan dan kinerja keuangan suatu entitas." Laporan ini menampilkan sejarah entitas yang dikuanlifikasi dalam nilai moneter. Menurut Kieso (2007) laporan keuangan merupakan sebuah sarana yang bisa digunakan oleh entitas untuk mengkomunikasikan keadaan terkait dengan kondisi keuangannya kepada pihak-pihak yang berkepentingan baik yang berasal dari internal entitas maupun eksternal entitas. SAK EMKM ditujukan pada usaha yang belum mampu memenuhi standar akuntansi Entitas Tanpa Akuntabilitas Publik (ETAP) yang berlaku sebelumnya. SAK EMKM dirancang lebih sederhana dibandingkan SAK ETAP. Sesuai dengan namanya, SAK EMKM dirancang khusus untuk Usaha Mikro, Kecil, dan Menengah sesuai Undang Undang No 20 Tahun 2008 yang berlaku aktif mulai 1 Januari 2018. Tujuannya adalah sebagai acuan dalam pembuatan laporan keuangan yang berisi informasi posisi dan kinerja keuangan. Informasi tersebut berguna bagi kreditor maupun investor untuk pengambilan keputusan ekonomi sekaligus pertanggungjawaban manajemen kepada pemilik usaha. Setidaknya, ada 3 Laporan Keuangan menurut SAK EMKM: (1) Laporan posisi keuangan (neraca); (2) Laporan laba rugi; dan (3) Catatan atas laporan keuangan, yang berisi tambahan dan rincian.

\section{Pengaruh Informasi dan Sosialisasi terhadap Penyusunan Laporan Keuangan}

Sosialisasi adalah sebagai proses penanaman atau transfer kebiasaan atau nilai dan aturan dari satu generasi ke generasi lainnya dalam sebuah kelompok atau masyarakat (Soekanto, 2009). Apabila UMKM diberikan sosialisasi tentang SAK EMKM maka mereka akan memperoleh informasi atau pengetahuan tentang SAK EMKM dan harapanya dengan menggunakan informasi tersebut mampu mendorong mereka untuk melakukan penyusunan laporan keuangan berdasarkan SAK EMKM. Hasil penelitian Maharani (2016) ditunjukan pemberian informasi dan sosialisasi mempunyai pengaruh positif signifikan terhadap pemahaman UMKM dalam penyusunan laporan keuangan berdasarkan SAK ETAP.

$\mathbf{H}_{\mathbf{1}}$ : Diduga Informasi dan sosialisasi berpengaruh positif signifikan terhadap Pemahaman UMKM dalam penyusunan Laporan Keuangan berdasarkan SAK EMKM.

\section{Pengaruh Latar Belakang Pendidikan terhadap Penyusunan Laporan Keuangan}

Latar belakang pendidikan adalah yang membedakan tingkat tinggi rendahnya pemahaman yang dimiliki oleh pengusaha UMKM (Rudiantoro dan Siregar, 2011). Latar belakang pendidikan selain ekonomi atau akuntansi cenderung lebih lama dalam memahami proses pembuatan laporan keuangan. Apabila latar belakang pendidikan pelaku usaha berasal dari ekonomi maka mereka cenderung mengerti tentang cara melaukan pembuatan laporan keuangan sesuai SAK EMKM dan latar belakang pendidikan sangat mempengaruhi cepat atau lambatnya pemahaman sesorang dalam memahami dan menguasai proses pembuatan laporan keuangan. Hasil penelitian Wicaksono (2016) dan Maharani (2016) ditunjukan latar belakang pendidikan pemilik UMKM mempunyai pengaruh positif signifikan terhadap pemahaman UMKM dalam penyusunan laporan keuangan berdasarkan SAK ETAP.

$\mathbf{H}_{2}$ : Diduga latar belakang pendidikan pemilik berpengaruh positif signifikan terhadap Pemahaman UMKM dalam penyusunan Laporan Keuangan berdasarkan SAK EMKM. 


\section{Pengaruh Lama Usaha terhadap Penyusunan Laporan Keuangan}

Lama usaha ditunjukan berdasarkan umur perusahaan berdasarkan tahun sejak pendirian peruahaan sampai dengan penelitian ini dilakukan (Rudiantoro, 2012). Semakin lama sebuah umur usahanya semakin tinggi, maka penggunaan informasi akuntansi akan semakin tinggi. Jadi lamanya sebuah usaha atau umur usaha UMKM sangat berpengaruh dengan pembuatan laporan keuangan. Semakin lama sebuah usaha tesebut berdiri maka semakin sering pula perusahaan itu melakukan sebuah pembukuan secara teratur setiap akhir bulan nya sehingga mampu mengetahui besarnya laba dan rugi dari usaha. Hasil penelitian Tuti dan Dwijayanti (2016), Wicaksono (2016) dan Maharani (2016) didapat umur usaha berpengaruh positif dan signifikan terhadap penggunaan informasi akuntansi pada UMKM dalam menyusun laporan keuangan berdasarkan SAK ETAP.

$\mathbf{H}_{3}$ : Diduga Lama Usaha berpengaruh positif signifikan terhadap Pemahaman UMKM dalam penyusunan Laporan Keuangan berdasarkan SAK EMKM.

\section{Pengaruh Ukuran Usaha terhadap Penyusunan Laporan Keuangan}

Ukuran usaha merupakan skala yang menunjukan besar kecilnya sebuah perusahaan, dilihat dari jumlah karyawan, volume penjualan dan nilai aset yang dimiliki (Longenecker, 2001 dalam Tuti dan Dwijayanti, 2016). Ukuran usaha dapat mempengaruhi pemikiran pengusaha terkait dengan kompleksitas dan semakin tingginya tingkat transaksi perusahaan sehingga diharap dengan makin besarnya ukuran usaha dapat mendorong seorang untuk berpikir dan belajar terkait solusi untuk menghadapinya. Jadi besar kecilnya ukuran usaha UMKM mempengaruhi pemahama UMKM dalam penyusunan laporan keuangan berdasarkan SAK EMKM, dikarenakan semakin besar ukuran usaha yang dijalankannya akan berpengaruh terhadap penggunaan informasi akuntansi dan laporan keuangan sesuai SAK EMKM. Hasil penelitian Tuti dan Dwijayanti (2016), Wicaksono (2016) dan Maharani (2016) ditunjukan ukuran usaha mempunyai pengaruh positif signifikan tehadap pemahaman UMKM dalam penyusunan laporan keuangan berdasarkan SAK ETAP.

$\mathbf{H}_{4}$ : Diduga Ukuan Usaha berpengaruh positif signifikan terhadap Pemahaman UMKM dalam penyusunan Laporan Keuangan berdasarkan SAK EMKM.

\section{Persepsi Pemahaman Pengusaha Dalam Penyusunan Laporan Keuangan Berdasarkan SAK EMKM Pada UMKM Kabupaten Jepara}

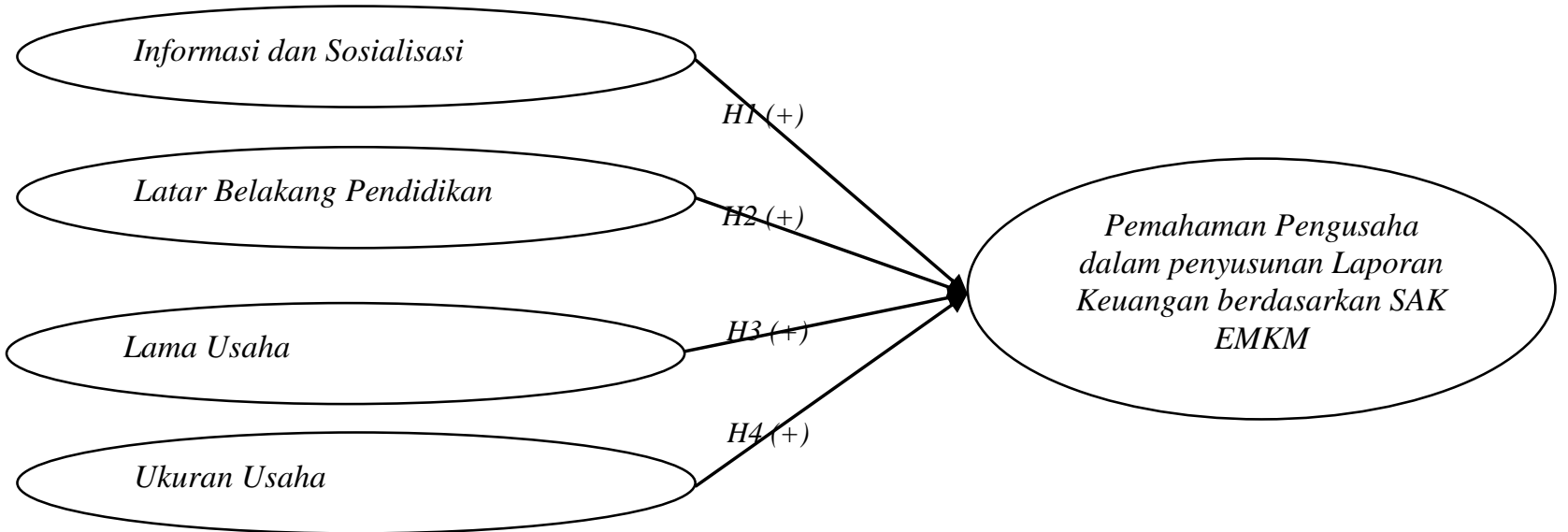

Gambar 1. Kerangka Pemikiran

Sumber data diolah, 2019.

\section{METODE}

\section{Definisi Operasional dan Pengukuran Variabel}

Informasi dan sosialisasi adalah transfer atau penyampaian sebuah informasi pengetahuan kepada orang lain dengan tujua orang tersebut mengetahui dan informasinya akan bertambah (Soekanto, 2009). Informasi dan Sosialisasi diukur menggunakan indikator : Mendapatkan sosialisasi pelatihan mengenai SAK EMKM; Informasi tentang SAK EMKM; dan Sosialisasi dan seminar yang berhubungan dengan SAK 
EMKM (Maharani, 2016). Latar belakang pendidikan adalah yang membedakan tingkat tinggi rendahnya pemahaman yang dimiliki oleh pengusaha UMKM (Rudiantoro dan Siregar, 2011). Latar belakang pendidikan diukur menggunakan indikator: latar belakang pendidikan ekonomi/akuntansi diberi skor 2; dan Latar belakang selain ekonomi/akuntansi diberi skor 1 (Wicaksono, 2016). Lama usaha ditunjukan berdasarkan umur perusahaan berdasarkan tahun sejak pendirian peruahaan sampai dengan penelitian ini dilakukan (Rudiantoro, 2012). Lama usaha diukur menggunakan indikator: Umur sebuah UMKM sejak dijalankan sampai saat penelitian dilakukan (Tuti dan Dwijayanti, 2016). Ukuran usaha merupakan skala yang menunjukan besar kecilnya sebuah perusahaan, dilihat dari jumlah karyawan, volume penjualan dan nilai aset yang dimiliki (Longenecker, 2001 dalam Tuti dan Dwijayanti, 2016). Indikator ukuran usaha menurut World Bank UMKM dikelompokkan menjadi tiga: 1) Jumlah karyawan Micro Enterprise, dengan kriteria kurang dari 10 orang; 2) Jumlah karyawan Small Enterprise, dengan kriteria kurang dari 30 orang; dan 3) Jumlah karyawan Medium Enterprise, dengan kriteria jumlah karyawan maksimum 300 orang. Pemahaman Pengusaha UMKM dalam penyusunan laporan keuangan merupakan pemahaman UMKM terhadap laporan keuangan SAK ETAP yang akan mendukung proses implementasi laporan keuangan berdasar SAK ETAP yang dapat membantu UMKM dalam mengembangkan usahanya (Rudiantoro dan Siregar, 2011). Pemahaman Pengusaha UMKM dalam penyusunan laporan keuangan berdasarkan SAK EMKM diukur dengan indikator: Pemahaman UMKM tentang penyusunan Laporan Keuangan sesuai SAK EMKM; dan Pemahaman UMKM tentang pentingnya penysunan Laporan Keuangan bagi perusahaan (Maharani, 2016).

\section{Populasi dan Sampel}

Populasi adalah pemilik UMKM kerajinan meubel furniture yang berada di wilayah Kecamatan Kota Jepara, sampai pada tahun 2019 sebanyak 197 (BPS, 2020). Sampel dihitung menggunakan rumus Slovin:

$$
\frac{N}{1+N(e)^{2}}=\frac{197}{1+197(0,1)^{2}}=66,32
$$

Teknik sampling penelitian menggunakan random sampling adalah teknik pengambilan sampel dimana semua individu dalam populasi baik secara sendiri-sendiri atau bersama-sama diberi kesempatan yang sama untuk dipilih sebagai anggota sampel (Sugiyono, 2016).

\section{Teknik Pengumpulan Data}

Metode pengumpulan data yang digunakan dalam penelitian ini adalah metode kuesioner. Kuesioner langsung diantar ke lokasi penelitian atau dengan pengiriman melalui email. Jawaban-jawaban responden diberi nilai atau skor dengan menggunakan skala likert, yaitu sangat setuju (skor 5), setuju (skor 4), kurang setuju (skor 3), tidak setuju (skor 2), dan sangat tidak setuju (skor 1) (Likert, 1932).

\section{Teknik Analisis Data}

Analisis data dalam penelitian ini menggunakan analisis secara kuantitatif, meliputi: uji validitas dan reliabilitas, uji asumsi klasik, analisis regresi berganda, dan pengujian hipotesis.

\section{Uji Validitas dan Reliabilitas}

Cara mengukur valid atau tidaknya dalam penelitian ini dengan membandingkan nilai $r$ hitung (corrected item total correlation) dengan $r$ tabel, pada $n$, sedangkan $n=$ jumlah sampel (Ghozali, 2018). Jika $R$ hitung > R tabel maka item pertanyaan valid. Dan suatu konstruk atau variabel dikatakan reliabel jika memiliki alpha $>0,60$ (Ghozali, 2018).

\section{Uji Asumsi Klasik}

Uji Normalitas, menggunakan histogram dan grafik normal P-P Plot dengan cara melihat penyebaran datanya. Data berdistribusi normal, jika menyebar di sekitar garis diagonal dan mengikuti arah garis histogram menuju pola distribusi normal. Uji Multikolonieritas, dilihat dari nilai tolerance dan varianceinflation factor (VIF). Untuk menunjukkan tidak ada multikolonieritas adalah Tolerance $>0,10$ atau nilai VIF < 10. Uji Heteroskesdastisitas, dilakukan dengan uji Glejser, jika nilai signifikan > 0,05 maka disimpulkan model regresi tidak mengandung adanya heteroskedastisitas. (Ghozali, 2018). 


\section{Analisis Regresi Berganda}

Analisis regresi berganda merupakan regresi yang memiliki satu variabel dependen dan lebih dari satu variabel independen (Ghozali, 2018). Analisis regresi berganda digunakan untuk mengetahui pengaruh Informasi dan Sosialisasi, Latar belakang pendidikan, Lama Usaha, dan Ukuran Usaha terhadap Pemahaman UMKM dalam penyusunan Laporan Keuangan berdasarkan SAK EMKM di Kabuapten Jepara. Persamaan regresi berganda adalah:

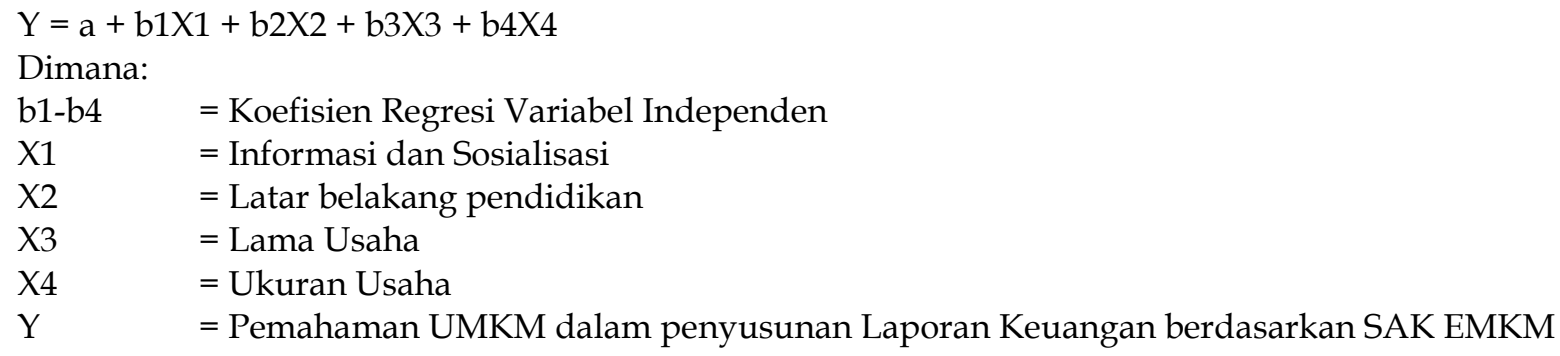

\section{Pengujian Hipotesis}

Uji Simultan (Uji F), untuk menunjukkan apakah semua variabel independen yang diasumsikan dalam model mempunyai pengaruh secara bersama-sama terhadap variabel dependen (Ghozali, 2018). Kriteria pengujian, yaitu: jika nilai sig. $<0,05$, menunjukkan model regresi dapat digunakan untuk menguji pengaruh variabel independen terhadap variabel dependen. Jika nilai sig. $>0,05$, menunjukkan bahwa model yang digunkan belum mampu menguji pengaruh variabel independen terhadap variabel dependen.

Uji Individual (Uji t), untuk menunjukkan seberapa jauh pengaruh satu variabel independen secara individual dalam menerangkan variasi variabel dependen (Ghozali, 2018). Kriteria pengujian: Jika nilai sig. $<0,05$, maka Ho ditolak dan Ha diterima, berarti secara parsial ada pengaruh signifikan antara variabel independen terhadap variabel dependen. Jika nilai sig. $\geq 0,05$, maka Ho diterima dan Ha diterima, berarti secara parsial tidak ada pengaruh antara variabel independen dengan variabel dependen.

\section{HASIL}

\section{Uji Validitas dan Reliabilitas}

Uji validitas dilakukan dengan membandingkan nilai r-hitung (Corrected Item-Total Correlation) dengan $\mathrm{r}$ tabel. Data dinyatakan valid jika nila $r$-hitung $>\mathrm{r}$-tabel pada signifikansi 0,05 . Dengan $\mathrm{df}=\mathrm{N}-2=66-2=64$ dan taraf signifikan 0,05 diketahui r-tabel $=0,244$. Hasil uji validitas ditunjukkan pada tabel 1 berikut ini.

Tabel 1. Uji Validitas

\begin{tabular}{lcccc}
\hline \multicolumn{1}{c}{ Variabel } & $\begin{array}{c}\text { Item } \\
\text { Pertanyaan }\end{array}$ & $\begin{array}{c}\text { r-hitung } \\
\text { (Corrected Item Total } \\
\text { Correlation) }\end{array}$ & r-tabel & Keterangan \\
\hline Informasi dan & X1.1 & 0,633 & 0,244 & Valid \\
Sosialisasi (X1) & X1.2 & 0,657 & 0,244 & Valid \\
& X1.3 & 0,501 & 0,244 & Valid \\
\hline Latar Belakang & X2.1 & 0,498 & 0,244 & Valid \\
Pendidikan (X2) & X2.2 & 0,856 & 0,244 & Valid \\
\hline & Y.1 & 0,530 & 0,244 & Valid \\
Pemahaman & Y.2 & 0,527 & 0,244 & Valid \\
UMKM dalam & Y.3 & 0,471 & 0,244 & Valid \\
penyusunan & Y.4 & 0,534 & 0,244 & Valid \\
Laporan & Y.5 & 0,435 & 0,244 & Valid \\
Keuangan & Y.6 & 0,517 & 0,244 & Valid \\
Berdasarkan & Y.7 & 0,437 & 0,244 & Valid \\
SAK EMKM (Y) & Y.8 & 0,462 & 0,244 & Valid \\
& Y.9 & 0,577 & 0,244 & Valid \\
& Y.10 & 0,513 & 0,244 & Valid \\
\hline
\end{tabular}

Sumber: data primer diolah, 2020. 
Berdasarkan data pada tabel 1, dapat dijelaskan bahwa nilai r-hitung (corrected item total correlation) dari setiap item pertanyaan lebih besar dari $r$ tabel $(0,244)$, sehingga dapat disimpulkan instrumen variabel Informasi dan Sosialisasi, Latar Belakang Pendidikan, dan Pemahaman UMKM dalam penyusunan Laporan Keuangan Berdasarkan SAK EMKM menunjukkan bahwa valid.

Uji reliabilitas digunakan menguji konsistensi dari jawaban yang diberikan oleh responden terhadap pernyataan yang diberikan. Instrumen dikatakan reliabel jika koefisien Cronbach Alpha > 0,60. Hasil uji reliabilitas ditunjukkan pada tabel 2 berikut ini:

Tabel 2. Uji Reliabilitas

\begin{tabular}{|c|c|c|c|}
\hline Variabel & Cronbach Alpha & Ukuran Reliabel & Keterangan \\
\hline Informasi dan Sosialisasi & 0,702 & $>0,60$ & Reliabel \\
\hline $\begin{array}{l}\text { Latar Belakang } \\
\text { Pendidikan }\end{array}$ & 0,743 & $>0,60$ & Reliabel \\
\hline $\begin{array}{l}\text { Pemahaman UMKM } \\
\text { dalam penyusunan } \\
\text { Laporan Keuangan } \\
\text { Berdasarkan SAK EMKM }\end{array}$ & 0,715 & $>0,60$ & Reliabel \\
\hline
\end{tabular}

Sumber: data primer diolah, 2020.

Berdasarkan data pada tabel 2 di atas, hasil uji reliabilitas dapat diketahui bahwa nilai cronbach alpha dari variabel Informasi dan Sosialisasi adalah sebesar 0,702 >0,60; nilai cronbach alpha untuk variabel Latar Belakang Pendidikan sebesar 0,743 >0,60; dan nilai cronbach alpha untuk Pemahaman UMKM dalam penyusunan Laporan Keuangan Berdasarkan SAK EMKM sebesar 0,715 > 0,60, jadi dapat disimpulkan bahwa instrumen dari seluruh variabel penelitian adalah reliabel

\section{Uji Asumsi Klasik}

Uji normalitas dilakukan untuk melihat data terdistribusi normal. Untuk menguji kenormalan data penelitian ini menggunakan grafik normal P-P Plot. Jika pada grafik tersebut penyebaran datanya mengikuti pola garis diagonal, maka data dikatakan terdistribusi normal. Hasil uji normalitas ditunjukkan pada gambar 2 berikut ini:

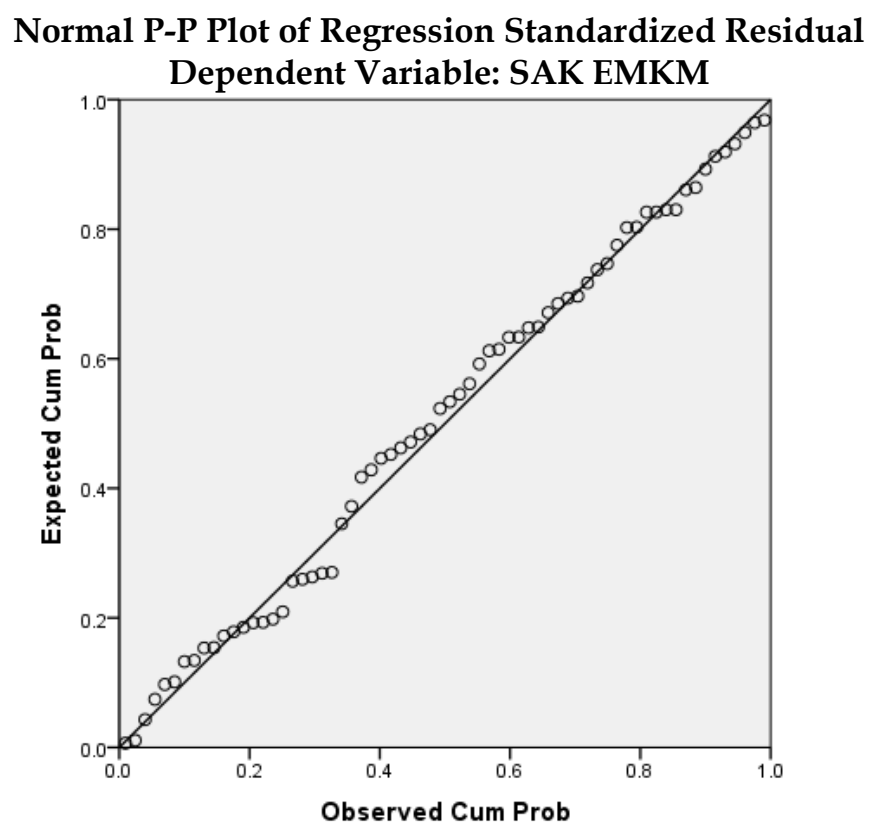

Gambar 2. Uji Normal P-P Plot

Sumber: data primer diolah, 2020. 
Berdasarkan gambar 2 di atas, dapat dilihat penyebaran data mengikuti garis diagonal, dengan demikian data dalam penelitian berdistribusi normal dan model regresi telah memenuhi asumsi normalitas.

Uji multikolinearitas diperlukan untuk menguji apakah ada hubungan yang signifikan antara variabel yang diteliti, karena apabila terjadi multikolinearitas maka kekuatan data dalam memprediksi menjadi tidak handal dan tidak stabil. Sehingga multikol menjadi syarat wajib bila data ingin diteliti lebih lanjut. Untuk menguji adanya multikolinieritas dengan melihat nilai variance inflantion factor (VIF) dan toleransi.

Jika VIF $<10$ dan tolerance $>0,1$ maka tidak terjadi multikolinieritas. Hasil uji multikolinearitas ditunjukkan pada tabel 3 berikut ini.

Tabel 3. Uji Multikolinearitas

\begin{tabular}{lcc}
\hline \multicolumn{1}{c}{ Variabel } & Tolerance & VIF \\
\hline $\begin{array}{l}\text { Informasi dan } \\
\text { sosialisasi }\end{array}$ & 0,965 & 1,036 \\
Latar Belakang & 0,835 & 1,197 \\
Pendidikan & 0,916 & 1,091 \\
Lama Usaha & 0,793 & 1,260 \\
Ukuran Usaha & \multicolumn{2}{c}{ Sumber: data primer diolah (2020) }
\end{tabular}

Berdasarkan data pada tabel 3 di atas diketahui bahwa variable Informasi dan sosialisasi memiliki nilai tolerance 0,965 > 0,1 dan nilai VIF 1,036 < 10; variabel Latar Belakang Pendidikan memiliki nilai tolerance $0,835>0,1$ dan nilai VIF 1,197 < 10; variabel Lama Usaha memiliki nilai tolerance 0,916>0,1 dan nilai VIF $1,091<10$, dan variabel Ukuran Usaha memiliki nilai tolerance 0,793 $>0,1$ dan nilai VIF $1,260<10$. Nilai tolerance dari setiap variabel lebih besar dari 0,1 dan nilai VIF kurang dari 10, maka dapat dikatakan bahwa semua variabel lulus uji multikolinearitas.

Uji Heteroskesdastisitas, dikatakan tidak terjadi heteroskedastisitas apabila titik menyebar di atas dan juga di bawah angka 0 pada sumbu Y (Ghozali, 2018). Hasil uji heteroskedastisitas ditunjukkan pada gambar 3 berikut ini.

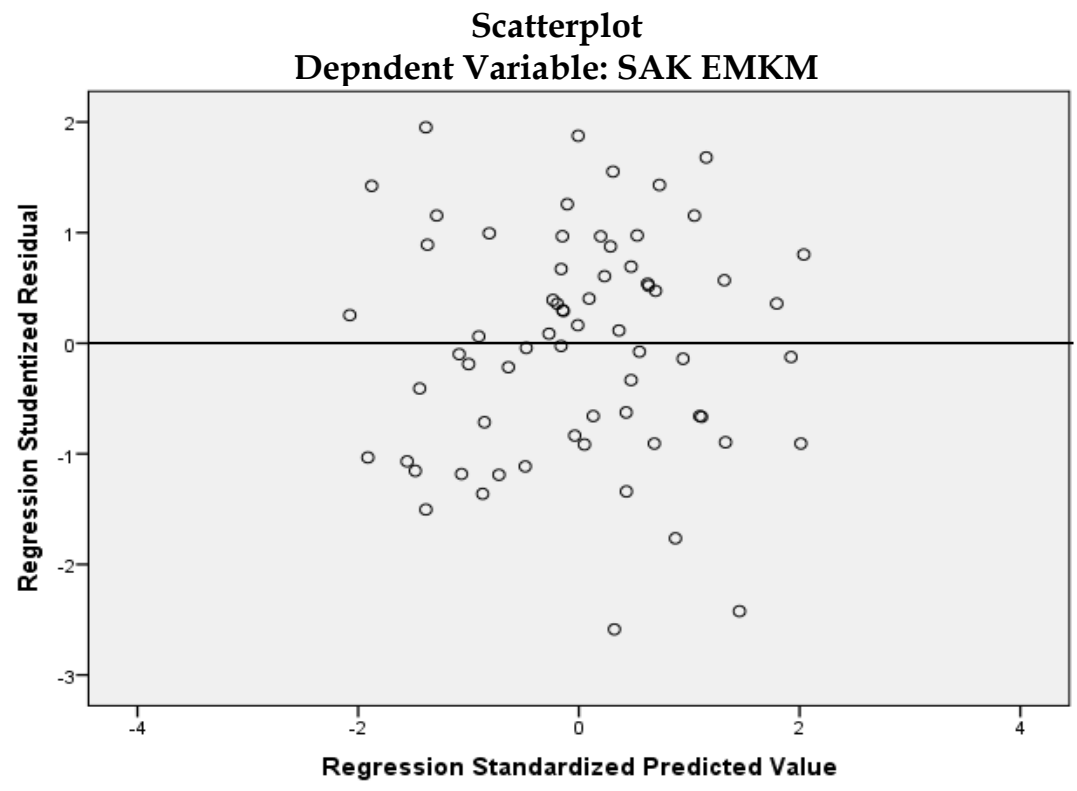

Gambar 3. Uji Heteroskedastisitas

Sumber: data primer yang diolah (2020)

Berdasarkan gambar 3 diketahui bahwa titik-titik menyebar secara acak serta tersebar di atas dan juga di bawah angka 0 pada sumbu Y. Jadi dapat disimpulkan bahwa tidak terjadi heteroskedastisitas sehingga model regresinya layak untuk digunakan 


\section{Analisis Regresi Linier Berganda}

Analisis regresi linear berganda dalam penelitian ini digunakan untuk mengetahui pengaruh variabel independen (bebas) terhadap variabel dependen (terikat). Berikut ini merupakan hasil uji regresi linier berganda menggunakan IBM SPSS Statistics 20 dan selanjutnya akan dimasukkan ke dalam persamaan regresi linier berganda untuk dianalisis

Tabel 4. Hasil Uji Regresi Linier Berganda

\begin{tabular}{|c|c|c|c|c|c|c|}
\hline \multicolumn{7}{|c|}{ Coefficients ${ }^{a}$} \\
\hline & \multirow[t]{2}{*}{ Model } & \multicolumn{2}{|c|}{ Unstandardized Coefficients } & \multirow{2}{*}{$\begin{array}{c}\begin{array}{c}\text { Standardized } \\
\text { Coefficients }\end{array} \\
\text { Beta } \\
\end{array}$} & \multirow[t]{2}{*}{$\mathrm{t}$} & \multirow[t]{2}{*}{ Sig. } \\
\hline & & $\mathrm{B}$ & Std. Error & & & \\
\hline \multirow{5}{*}{1} & (Constant) & 6.421 & 3.150 & & 2.039 & .046 \\
\hline & Informasi Dan Sosialisasi & .509 & .244 & .190 & 2.084 & .041 \\
\hline & Latar Belakang Pendidikan & 1.142 & .429 & .261 & 2.665 & .010 \\
\hline & Lama Usaha & .134 & .061 & .205 & 2.195 & .032 \\
\hline & Ukuran Usaha & 1.547 & .617 & .252 & 2.505 & .015 \\
\hline
\end{tabular}

a. Dependent Variable: SAK EMKM

Sumber: data primer diolah (2020)

Berdasarkan data yang ditunjukkan pada tabel 5 di atas, maka persamaan regresi linear berganda dapat disusun sebagai berikut : $Y=0,190 X_{1}+0,261 X_{2}+0,205 X_{3}+0,252 X_{4}$. Dari hasil persamaan tersebut, dapat diinterpretasikan untuk koefisien regresi variabel Informasi dan Sosialisasi (X1) sebesar 0,190, berarti Informasi dan Sosialisasi berpengaruh positif terhadap Pemahaman UMKM dalam penyusunan Laporan Keuangan Berdasarkan SAK EMKM, sehingga setiap peningkatan Informasi dan Sosialisasi akan mengakibatkan peningkatan Pemahaman UMKM dalam penyusunan Laporan Keuangan Berdasarkan SAK EMKM. Interpretasi untuk koefisien regresi variabel Latar Belakang Pendidikan (X2) sebesar 0,261, berarti Latar Belakang Pendidikan memiliki pengaruh positif terhadap Pemahaman UMKM dalam penyusunan Laporan Keuangan Berdasarkan SAK EMKM, sehingga setiap pengusaha memiliki Latar Belakang Pendidikan ekonomi/akuntansi maka akan mengakibatkan peningkatan Pemahaman UMKM dalam penyusunan Laporan Keuangan Berdasarkan SAK EMKM. Interpretasi untuk koefisien regresi variabel lama usaha (X3) sebesar 0,205, berarti lama usaha memiliki pengaruh positif terhadap Pemahaman UMKM dalam penyusunan Laporan Keuangan Berdasarkan SAK EMKM, sehingga setiap UMKM sudah semakin lama berdiri maka akan mengakibatkan peningkatan Pemahaman UMKM dalam penyusunan Laporan Keuangan Berdasarkan SAK EMKM. Interpretasi untuk koefisien regresi variabel Ukuran Usaha (X4) sebesar 0,252, berarti Ukuran Usaha memiliki pengaruh positif terhadap Pemahaman UMKM dalam penyusunan Laporan Keuangan Berdasarkan SAK EMKM, sehingga setiap UMKM sudah semakin lama berdiri maka akan mengakibatkan peningkatan Pemahaman UMKM dalam penyusunan Laporan Keuangan Berdasarkan SAK EMKM.

\section{Uji Hipotesis t}

Uji t digunakan untuk mengetahui tentang seberapa jauh masing-masing variabel berpengaruh secara individu/parsial terhadap variabel terikat. Variabel dikatakan memiliki pengaruh yang signifikan apabila nilai sig $<0,05$. Untuk mengetahui hasil uji $t$ dengan cara membandingkan $t$ hitung dengan $t$ tabel, apabila $t$ hitung $>\mathrm{t}$ tabel, maka hipotesis diterima. Dengan $\mathrm{df}=\mathrm{n}-\mathrm{k}, \mathrm{df}=66-4=62$, dengan tingkat signifikan 0,05 diketahui $t$ tabel senilai 1,6698. Hasil uji t ditunjukkan pada tabel 6 berikut ini.

Tabel 5. Uji t

\begin{tabular}{lll}
\hline Model & $\mathrm{T}$ & Sig. \\
\hline (Constant) & 2.039 & .046 \\
Informasi dan Sosialisasi & 2.084 & .041 \\
Latar Belakang Pendidikan & 2.665 & .010 \\
Lama Usaha & 2.195 & .032 \\
Ukuran Usaha & 2.505 & .015 \\
\hline
\end{tabular}

Sumber: Data Primer yang diolah (2020) 
Pengaruh Informasi dan Sosialisasi Terhadap Pemahaman UMKM dalam penyusunan Laporan Keuangan Berdasarkan SAK EMKM

Berdasarkan data pada tabel 6, dapat dijelaskan bahwa variabel Informasi dan Sosialisasi mempunyai nilai signifikan $0,041<\alpha=0,05$ dan nilai $t$ hitung sebesar 2.084 lebih besar dari nilai $t$ tabel sebesar 1,6698, hal ini berarti Informasi dan Sosialisasi berpengaruh positif signifkan terhadap Pemahaman UMKM dalam penyusunan Laporan Keuangan Berdasarkan SAK EMKM. Artinya jika Informasi dan Sosialisasi meningkat maka Pemahaman UMKM dalam penyusunan Laporan Keuangan Berdasarkan SAK EMKM juga meningkat. Dengan demikian hipotesis pertama yang menyatakan "Diduga Informasi dan Sosialisasi berpengaruh positif signifikan pada Pemahaman UMKM dalam penyusunan Laporan Keuangan Berdasarkan SAK EMKM" diterima.

\section{Pengaruh Latar Belakang Pendidikan Terhadap Pemahaman UMKM dalam penyusunan Laporan Keuangan Berdasarkan SAK EMKM}

Berdasarkan data pada tabel 6, dapat dijelaskan bahwa variabel Latar Belakang Pendidikan mempunyai nilai signifikan $0,010<\mathrm{a}=0,05$ dan nilai $\mathrm{t}$ hitung sebesar 2,665 lebih besar dari nilai $\mathrm{t}$ tabel sebesar 1,6698, hal ini berarti Latar Belakang Pendidikan berpengaruh positif signifikan terhadap Pemahaman UMKM dalam penyusunan Laporan Keuangan Berdasarkan SAK EMKM. Artinya apabila pengusaha UMKM semakin memiliki Latar Belakang Pendidikan ekonomi/akuntansi akan mempengaruhi meningkatnya Pemahaman UMKM dalam penyusunan Laporan Keuangan Berdasarkan SAK EMKM. Dengan demikian hipotesis kedua yang menyatakan "Diduga Latar Belakang Pendidikan berpengaruh positif signifikan pada Pemahaman UMKM dalam penyusunan Laporan Keuangan Berdasarkan SAK EMKM" diterima.

\section{Pengaruh Lama Usaha Terhadap Pemahaman UMKM dalam penyusunan Laporan Keuangan Berdasarkan SAK EMKM}

Berdasarka data pada tabel 6, dapat dijelaskan bahwa variabel Lama Usaha mempunyai nilai signifikan 0,032 < $\alpha=0,05$ dan nilai thitung sebesar 2,195 lebih besar dari nilai t tabel sebesar 1,6698, hal ini berarti Lama Usaha berpengaruh positif signifkan terhadap Pemahaman UMKM dalam penyusunan Laporan Keuangan Berdasarkan SAK EMKM. Artinya jika perusahaan semakin lama berusaha maka Pemahaman UMKM dalam penyusunan Laporan Keuangan Berdasarkan SAK EMKM juga meningkat. Dengan demikian hipotesis ketiga yang menyatakan "Diduga Lama Usaha berpengaruh positif signifikan pada Pemahaman UMKM dalam penyusunan Laporan Keuangan Berdasarkan SAK EMKM" diterima.

\section{Pengaruh Ukuran Usaha Terhadap Pemahaman UMKM dalam penyusunan Laporan Keuangan Berdasarkan SAK EMKM}

Berdasarkan data pada tabel 6, dapat dijelaskan bahwa variabel Ukuran Usaha mempunyai nilai signifikan 0,032< $\alpha=0,05$ dan nilai thitung sebesar 2,195 lebih besar dari nilai $t$ tabel sebesar 1,6698, hal ini berarti Ukuran Usaha berpengaruh positif signifkan terhadap Pemahaman UMKM dalam penyusunan Laporan Keuangan Berdasarkan SAK EMKM. Artinya jika perusahaan semakin besar maka Pemahaman UMKM dalam penyusunan Laporan Keuangan Berdasarkan SAK EMKM juga meningkat. Dengan demikian hipotesis keempat yang menyatakan "Diduga Ukuran Usaha berpengaruh positif signifikan pada Pemahaman UMKM dalam penyusunan Laporan Keuangan Berdasarkan SAK EMKM" diterima

\section{PEMBAHASAN}

\section{Pengaruh Informasi dan Sosialisasi Terhadap Pemahaman UMKM dalam penyusunan Laporan Keuangan Berdasarkan SAK EMKM}

Hasil pengujian hipotesis pertama (H1), diketahui bahwa variabel Informasi dan Sosialisasi berpengaruh positif signifikan terhadap Pemahaman UMKM dalam penyusunan Laporan Keuangan, dibuktikan dengan diperoleh nilai $t$ hitung $>t$ tabel $(2,084>1,6698)$ dan tingkat signifikansi $0,041<0,05$ yang berarti Ho ditolak Ha diterima. Hasil tersebut menunjukan bahwa Informasi dan Sosialisasi merupakan faktor penting terkait dengan tingkat pemahaman UMKM dalam penyusunan laporan keuangan berdasarkan SAK ETAP. Hasil penelitian ini sesuai dengan teori Soekanto (2009), bahwa sosialisasi adalah sebagai proses penanaman atau transfer kebiasaan atau nilai dan aturan dari satu generasi ke generasi lainnya dalam sebuah kelompok atau masyarakat. Apabila UMKM diberikan 
sosialisasi tentang SAK EMKM maka mereka akan memperoleh informasi atau pengetahuan tentang SAK EMKM dan harapanya dengan menggunakan informasi tersebut mampu mendorong mereka untuk melakukan penyusunan laporan keuangan berdasarkan SAK EMKM. Hasil penelitian ini sejalan atau selaras dan didukung dengan penelitian terdahulu yang di lakukan oleh Maharani (2016) ditunjukan pemberian informasi dan sosialisasi mempunyai pengaruh positif signifikan terhadap pemahaman UMKM dalam penyusunan laporan keuangan berdasarkan SAK ETAP.

\section{Pengaruh Latar Belakang Pendidikan Terhadap Pemahaman UMKM dalam penyusunan Laporan Keuangan Berdasarkan SAK EMKM}

Hasil hipotesis kedua (H2), diketahui bahwa variabel Latar Belakang Pendidikan berpengaruh positif signifikan terhadap Pemahaman UMKM dalam penyusunan Laporan Keuangan Berdasarkan SAK EMKM, dibuktikan dengan diperoleh nilai $t$ hitung $>t$ tabel $(2,665>1,6698)$ dan tingkat signifikansi $0,010<0,05$, berarti semakin Latar Belakang Pendidikan yang dimiliki pengusaha (berpendidikan ekonomi/akuntansi) maka akan mempengaruhi tingkat Pemahaman UMKM dalam penyusunan Laporan Keuangan Berdasarkan SAK EMKM semakin baik, sehingga Hipotesis H2 diterima. Hasil penelitian ini sesuai pendapat Rudiantoro dan Siregar (2011) yaitu latar belakang pendidikan adalah yang membedakan tingkat tinggi rendahnya pemahaman yang dimiliki oleh pengusaha UMKM. Latar belakang pendidikan selain ekonomi atau akuntansi cenderung lebih lama dalam memahami proses pembuatan laporan keuangan. Apabila latar belakang pendidikan pelaku usaha berasal dari ekonomi maka mereka cenderung mengerti tentang cara melaukan pembuatan laporan keuangan sesuai SAK EMKM dan latar belakang pendidikan sangat mempengaruhi cepat atau lambatnya pemahaman sesorang dalam memahami dan menguasai proses pembuatan laporan keuangan. Hasil penelitian ini sejalan atau selaras dan didukung dengan penelitian terdahulu yang dilakukan oleh Wicaksono (2016) dan Maharani (2016) ditunjukan latar belakang pendidikan pemilik UMKM mempunyai pengaruh positif signifikan terhadap pemahaman UMKM dalam penyusunan laporan keuangan berdasarkan SAK ETAP.

\section{Pengaruh Lama Usaha Terhadap Pemahaman UMKM dalam penyusunan Laporan Keuangan Berdasarkan SAK EMKM}

Hasil hipotesis ketiga (H3), diketahui bahwa variabel Lama Usaha berpengaruh positif signifikan terhadap Pemahaman UMKM dalam penyusunan Laporan Keuangan Berdasarkan SAK EMKM, dibuktikan dengan diperoleh nilai $t$ hitung $>t$ tabel $(2,195>1,6698)$ dan tingkat signifikansi $0,032<0,05$, berarti perusahaan yang sudah Lama Usaha mempengaruhi tingkat Pemahaman UMKM dalam penyusunan Laporan Keuangan Berdasarkan SAK EMKM. Hasil penelitian ini sesuai dengan teori Rudiantoro (2012) bahwa Lama usaha ditunjukan berdasarkan umur perusahaan berdasarkan tahun sejak pendirian peruahaan sampai dengan penelitian ini dilakukan. Semakin lama sebuah umur usahanya semakin tinggi, maka penggunaan informasi akuntansi akan semakin tinggi. Jadi lamanya sebuah usaha atau umur usaha UMKM sangat berpengaruh dengan pembuatan laporan keuangan. Semakin lama sebuah usaha tesebut berdiri maka semakin sering pula perusahaan itu melakukan sebuah pembukuan secara teratur setiap akhir bulan nya sehingga mampu mengetahui besarnya laba dan rugi dari usaha. Hasil penelitian ini sejalan dengan penelitian yang dilakukan oleh Tuti dan Dwijayanti (2016), Wicaksono (2016) dan Maharani (2016) didapat umur usaha berpengaruh positif dan signifikan terhadap penggunaan informasi akuntansi pada UMKM dalam menyusun laporan keuangan berdasarkan SAK ETAP.

\section{Pengaruh Ukuran Usaha Terhadap Pemahaman UMKM dalam penyusunan Laporan Keuangan Berdasarkan SAK EMKM}

Hasil hipotesis ketiga (H4), diketahui bahwa variabel Ukuran Usaha berpengaruh positif signifikan terhadap Pemahaman UMKM dalam penyusunan Laporan Keuangan Berdasarkan SAK EMKM, dibuktikan dengan diperoleh nilai $t$ hitung $>t$ tabel $(2,505>1,6698)$ dan tingkat signifikansi $0,015<0,05$, berarti perusahaan yang sudah Ukuran Usaha mempengaruhi tingkat Pemahaman UMKM dalam penyusunan Laporan Keuangan Berdasarkan SAK EMKM. Hasil penelitian ini sesuai dengan teori Long enecker (2001 dalam Tuti dan Dwijayanti, 2016) Ukuran usaha merupakan skala yang menunjukan besar kecilnya sebuah perusahaan, dilihat dari jumlah karyawan, volume penjualan dan nilai aset yang dimiliki.. Ukuran usaha dapat mempengaruhi pemikiran pengusaha terkait dengan kompleksitas dan semakin tingginya tingkat transaksi perusahaan sehingga diharap dengan makin besarnya ukuran usaha dapat 
mendorong seorang untuk berpikir dan belajar terkait solusi untuk menghadapinya. Jadi besar kecilnya ukuran usaha UMKM mempengaruhi pemahama UMKM dalam penyusunan laporan keuangan berdasarkan SAK EMKM, dikarenakan semakin besar ukuran usaha yang dijalankannya akan berpengaruh terhadap penggunaan informasi akuntansi dan laporan keuangan sesuai SAK EMKM. Hasil penelitian ini sejalan atau selaras dan didukung dengan penelitian terdahulu yang di lakukan oleh Tuti dan Dwijayanti (2016), Wicaksono (2016) dan Maharani (2016) ditunjukan ukuran usaha mempunyai pengaruh positif signifikan tehadap pemahaman UMKM dalam penyusunan laporan keuangan berdasarkan SAK ETAP.

\section{SIMPULAN DAN SARAN}

\section{SIMPULAN}

Informasi dan Sosialisasi berpengaruh positif signifikan terhadap Pemahaman UMKM dalam penyusunan Laporan Keuangan Berdasarkan SAK EMKM. Latar Belakang Pendidikan berpengaruh positif signifikan terhadap Pemahaman UMKM dalam penyusunan Laporan Keuangan Berdasarkan SAK EMKM. Lama Usaha berpengaruh positif signifikan terhadap Pemahaman UMKM dalam penyusunan Laporan Keuangan Berdasarkan SAK EMKM. Dan Lama Usaha berpengaruh positif signifikan terhadap Pemahaman UMKM dalam penyusunan Laporan Keuangan Berdasarkan SAK EMKM.

\section{SARAN}

Penelitian selanjutnya disarankan melakukan penelitian dengan jangkauan sampel diperluas, tidak hanya lingkup Kecamatan saja, lebih baik lingkup Kabupaten dan kemudian diperluas ke tingkat Provinsi. Obyek penelitian jangan pada bidang kerajinan meubel jepara saja, perluas ke bidang makanan atau kain tenun Troso. Dan untuk jumlah sampelnya lebih baik di atas 66 sampel, karena semakin banyak sampel maka semakin baik pula dengan hasilnya.

\section{DAFTAR PUSTAKA}

Alva, T. (2010). Perjalan Tujuan Hidupku. Dikutip Juli 26, 2016, dari Pengertian Sistem Informasi: atomaslaia.blogspot.co.id/2010/12/pengertian-sistem-informasi.html?m=1.

Baridwan, Z. (2000). Intermediate Accounting. ed. 7. Yogyakarta: BPFE : Yogyakarta.

Depdiknas. (2003). Undang-undang RI No.20 Tahun 2003 tentang Sistem Pendidikan Nasional.

Ghozali, Imam. (2018). Aplikasi Analisis Multivariate Dengan Program IBM SPSS. Edisi 9. Semarang: BP Universitas Diponegoro.

https://databoks.katadata.co.id/2020.

IAI. (2009). Standar Akuntansi Keuangan Entitas Tanpa Akuntabilitas Publik. Jakarta: Dewan Standar Akuntansi Keuagan.

Jogiyanto, (2010). Analisis dan Disain Informasi: Pendekatan Terstruktur Teori dan Praktek Aplikasi Bisnis. Yogyakarta : Andi Offset.

Kieso, Donald E., Jerry J. Weygandt, dan Terry D. Warfield (2007). Akuntansi Intermediete. Terjemahan Emil Salim, Jilid 1, Edisi Kesepuluh. Jakarta : Penerbit Erlangga.

Likert, Rensis (1932). A Technique for the Measurement of Attitudes. Archives of Psychology, vol. 140: p.1-55.

Maharani, Eka. (2016). Faktor-faktor yang mempengaruhi pemahaman usaha mikro kecil dan menengah dalam penyusunan laporan keuangan berdasarkan standar akuntansi keuangan entitas tanpa akuntanbilitas Publik. Repository UM Jember. Dikutip dari http:/ / repository.unmuhjember.ac.id/49/.

Purnamasari, V., A. A. Chrismastuti, dan S. D. Ayu. (2009). Faktor-Faktor Yang Mempengaruhi Penyiapan dan Penggunaan Informasi Akuntansi perusahaan Kecil dan Menengah (Studi Di Jawa Tengah). Artikel Tidak Dipublikasikan. Semarang. http://eprints.unika.ac.id.

Rudianto (2012). Pengantar Akuntansi. Jakarta : Erlangga.

Rudiantoro, R., dan S. V. Siregar. (2011). Kualitas Laporan Keuangan UMKM serta Prospek Implementasi SAK ETAP. Simposium Nasional Akuntansi XVI. Aceh. 21-22 Juli. 
Soekanto, Soerjono. (2009). Sosiologi suatu Pengantar. Jakarta : Rajawali Pers.

Sugiyono. (2016). Statistika Untuk Penelitian. Bandung: Alfabeta.

Sujiono, Yuliani Nurani dan Sujiono, Bambang. (2010). Pengertian Ukuran Usaha. Jakarta: PT Indeks.

Tuti, Rias., dan Dwijayanti, S, Patricia Febrina. (2016). Faktor-Faktor Yang Mempengaruhi Pemahaman UMKM Dalam Menyusunan Laporan Keuangan Berdasarkan SAK ETAP. Jurnal Akuntansi Kontemporer (JAKO) - Vol 8 No. 2 - Juli 2016 - Hal. 98-107.

UU Nomor 20 Tahun (2008) tentang UMKM.

Wicaksono. (2016). Analisis faktor-faktor yang mepengaruhi presepsi pelaku usaha mikro kecil menengah tentan pentinya pelaporan keuangan berdasarkan SAK ETAP (Studi empiris pada UMKM di Kabupaen Jember. UT-Faculty of Economic and Business. Dikutip dari http://repository.unej.ac.id/handle/123456789/73728. 